\title{
CULTURAL HYBRIDITY TOWARDS AN UPWARD MOBILITY: IMPLICATIONS OF THE AMERICAN MEDIA AND AMERICAN CORPORATE CULTURE IN INDONESIA
}

\author{
Alfred Inkiriwang \\ Management Graduate Program, Institut Bisnis \& Multimedia Asmi \\ ibm@asmi.ac.id \\ American Studies Graduate Program, Universitas Indonesia \\ kwa-ui@ui.ac.id \\ Riani E. Inkiriwang Winter \\ American Studies Graduate Program, Universitas Indonesia \\ kwa-ui@ui.ac.id \\ Master of Education Program, Universitas Pelita Harapan \\ Master of Communications Program, Universitas Pelita Harapan
}

\begin{abstract}
Hybridity has been defined in many terms. Subsequently, cultural hybridity is associated with different meanings, as seen from a spectrum of theoretical and disciplinary perspectives. In the realm of Transnational American Studies in Indonesia, the hybridization of American Media and American Corporate Culture into those domains in Indonesia would be an observable transnational cultural phenomenon. American corporate culture has a hegemonic dominance in the world as it has in Indonesia. Similarly, in the current global media culture, American media's influence has brought with it its culture to places throughout the world including Indonesia. In the current discourses hybridity has "long left behind the negative implications and connotations of inferiority" and it presents currently the intercultural exchange of transnational and global mobility. This article explores American and Indonesian cultural hybridity as a notion of upward mobility in the domain of media culture and corporate culture in Indonesia.
\end{abstract}

Keywords: cultural hybridity, upward mobility, American media, American corporate culture.

\section{INTRODUCTION}

Hybridity has been defined in various as well as contested terms. Subsequently, cultural hybridity is associated with different meanings as seen from a spectrum of theoretical and disciplinary perspectives. In the realm of Transnational American Studies in Indonesia, the hybridization of American media and American corporate \& management culture into those domains in Indonesia is an observable transnational cultural phenomenon. This article attempts to explain these American cultural productions, in particular their transnational direction towards Indonesia, and their subsequent encounter with the latter's local cultures. The arguments put forward are in the context of what is referred to as cultural hybridity. Questions then arose, such as: how did this kind of hybridity take place? How did it materialize? In what particular ways? The writers discuss the answers to these questions according to their observations and experiences in the hybridization processes. 
We will focus on the two above-named specific cultural products, i.e., the media and corporate \& management culture. The preference for this choice is twofold. Firstly, cultural production in the form of the American media as well as American management style and practices in operations have become, whether consciously or not, a familiar and observable sight in Indonesia, something the following sections of this article will bring forth. Secondly, this phenomenon has been the interest of the writers, and such have become subjects of discussion in classes at the American Studies program the writers are affiliated with.

As we see it, the two products, media and management culture, are being implemented almost as if they were the modes of production of local, Indonesian culture in the sense that there seem to be a sort of 'matter of fact' in the practice of these supposedly 'imported' cultures.

As mentioned before, hybridity, or sometimes hybridization, is a concept that is highly contested, in regard to what it constitutes as well as how it should be interpreted. Various scholars, researchers have termed the notion differently, seen from different angles, and even explained in different ways. It is obvious, then, regardless of or even due to, its controversy, that it is a topic that is worth analyzing. In fact, as stated by Kraidy (2005), this topic of hybridity "has entered many academic arenas, ranging from traditional disciplines like literature, anthropology, and sociology to interdisciplinary venues such as postcolonial theory and performance studies . . . also employed in more popular versions in trade books about travel, business, and economics, in addition to mainstream press articles on popular culture" ( $p$. 2). Ha (2006) describes cultural hybridity as a concept which

celebrates the dynamics of mixture and intermingling. [I]n a situation in which postmodern late capitalist economy calls for aesthetical and technological innovations through mixed and endless (re)composition ... cultural hybridity is . . not based on homogeneity, standardization or the myth of the isolated genius at work, but on inclusion and transgressions of images, languages, sounds and subjectivities to enrich a cultural flow that promises to lead us to a transglobal popular culture and dramatic change of values (n.p.)

He comments further that hybridity in a political economy context "sells well, because it is regarded sexy." Ha further argues that a new economy is created "based upon industrialization of models of hybridity." As one of the models Ha points to the music industry, which relies very much on hybridization and created various music styles. Some, Ha observes, are "hot, exotic and vivid hybrid music." Corresponding to Ha's descriptions, Raab \& Butler (2008) quote the definition by Elisabeth Bronfen and Benjamin Marius (1997) who state that hybrid is "everything that owes its existence to a mixture of traditions or 
chains of significations, everything that links different kinds of discourse and technologies, everything that came into being through techniques of collage, sampling or bricolage" ( $\mathrm{p}$. 1). Consequently, according to Bronfen and Marius, the concept of hybridity "questions ideas of purity and homogeneity hybridity" (p. 1). Tomlinson (1999) asserts that an appealing thought is that globalized culture is hybrid culture. The increasing interchange between culture practices in the process of globalization produces new complex hybrid forms of culture. But he warns that "the idea of cultural hybridization is one of those deceptively simple-seeming notions which turns out, on examination, to have lots of tricky connotations and theoretical implications" (p. 141). He states, "Perhaps the most basic component of the idea of hybridity is that of simple mixing - intermingling, combining, fusion, mélange ... . Hybridity is the mingling of cultures from different territorial locations brought about by the increasing traffic amongst cultures" ( $p$. 142).

Pieterse (2010) argues along the above theme that "mixing is intrinsic to the evolution of species ... and that hybridization is a process as old as history" (p. 1). What is increasing is the pace of mixing and widening of the scope of mixing due to among others new technologies that bring forward new forms of intercultural encounters. He defines globalization as a process of hybridization and that in a political economy context globalization refers to "economic internationalization and spread of capitalist market relations." A global economy is created which constitutes a system of globalizing production and global finance.

The common theme or denominator in all the above definitions or descriptions of hybridity is the mixing of cultures, which in the globalization process is accelerated through the rapid interchange of cultures. The usage of the Internet, texting and all types of internet applications created a world where all information and contacts are a few clicks away. The YouTube videos available on the Internet and that are freely accessible make it possible to get hold of all sort of knowledge and view all types of cultures. The internet applications created global virtual communities, those communities interchanged ideas, knowledge and cultures to an unprecedented level. Another phenomenon that brought the acceleration of hybridization were the down spiral of the cost of flying. Air travel, domestic and international became affordable to the common people. Global commerce and business transactions reached all levels of the business community. Farmers could obtain the same information of the global commodity market as the CEO's of transnational corporations. Borders became irrelevant in the cyber-space. The world was reachable in clicks. Globalization or what Pieterse calls "the process of hybridization" irreversible transgressed and influenced the life of common people throughout the world. Tomlinson (1999) observed that the "mingling of cultures from different territorial locations brought about 
by the increasing traffic amongst cultures" (p. 142) through the use of cyberspace was not anymore a monopoly and power of the West. Because hybridity has been so widely analyzed in such varied domains with often-contradictory use, it would be 'risky', in Kraidy's (2005) terms, to use hybridity as a universal description. He emphasizes, consequently, that it would be "imperative to situate every analysis of hybridity in a specific context where the conditions that shape hybridity's are addressed" ( $p$ vi).

Following this argument, we restate that hybridity in this article will be seen in the context of 'upward mobility'. In more current discourses, hybridity, as Raab and Butler opine, "has long left behind the negative implications and connotations of inferiority" (p. 1), as compared to the decades between 1960-1980 when hybridity was analyzed in the realm of cultural imperialism bringing with it the negativities influencing a cultural mix. The way we see it, the concept of hybridity in present times has shifted, bringing to the fore the intercultural exchange of transnational and global mobility. Our take in this phenomenon is that the cultural mixture tends to direct to an upward mobility as opposed to "connotations of inferiority," which we elaborate in the coming paragraphs. Upward mobility can be defined from the point of view of the "capacity or facility for rising to a higher social or economic position." (Merriam Webster's online dictionary, highlight by writers). Apart from capacity, this definition mentions the facility for upward mobility. In this article the emphasis of the said movement is on the facility, since we portray our thoughts on the hybrid media and management culture's function as a facility in the move upwards for those employing the cultures, be it individually or socially.

We look in particular at selected instances when American media and American corporate management culture come into contact with Indonesian cultures in those specific domains. In the case of the media, the writers look into the encounter of American news and entertainment media's culture in its practical utilization by the Indonesian media people, the practitioners as well as the users (audience). In the domain of corporate management culture observe the American management culture as practiced in this country.

\section{AMERICAN MEDIA}

In the current global media culture American media products have been observed to be incredibly pervasive. From hardware-gadgetsto software (TV programs, social media portals, webs, blogs), American media products are widely used in the world. Already in the year 1997, Jeremy Tunstall in his insightful classic observed how 'the media are American', iterating that media innovations made in America were, as he sees it, 'copied' throughout the world. Tunstall illustrated how in the era of the print media, a country in Africa literally 'copied' the American newspaper: its form, content, and distribution. Compared to the United States, this African younger state had fewer inhabitants to subscribe to the newspaper; 
had fewer literates to read the content; had fewer newsworthy events to fill the pages; had less transportation to distribute the papers. Tunstall also observed that television, America's subsequent media production, enjoyed the same mimicry. Its shape (rectangular), its function (domestic use as opposed to public), its place (the living room) experienced no changes when used in different countries of the world. This illustrates how the American media did have an profound impact in the global media at the time Tunstall did his research. "One major influence of American imported media lies in the styles and patterns which most other countries in the world have adopted and copied," states Tunstall (p. 17). Starting from the 'older' media (newspaper, magazine, telegraph, radio, television) to the 'new' media, digital (computer, smart phone, tablet), the world imitated the United States, its media hardware as well as its software.

Media culture analysis proposes three components to be looked into: production; representation; reception (Kellner, 1995), in other words, to look into media's industry, texts, and audiences, respectively. According to Kellner and Durham (2006) “conjoining production/text/audience perspectives can . . help provide a more complex sense of how culture and media actually operate in everyday life" (p. xii). In the context of American media culture the combined media components in a subtle way communicate the American culture embedded in all the types of media used.
Mass media is considered one of the most powerful tools of communication. It is the getting across of messages. Information is conveyed to the masses, hence the term mass media. Through the decades of its growth and changes in methods, the mass media has become an dynamic means of communicating messages, discussing, shaping, depicting, arguing, and reflecting values, behaviors, and actions of different cultures. In fact, the media world has become our world, in the sense that we are living in a world that is bombarded by messages from the media; the culture we live in is a media culture. Potter (2008) asserts that the world's culture is "saturated with information. The flood of messages comes to us through the mass media . . . The world is rapidly changing because of DVD's, computers, MP3 players, cell phones, Black Berries, and many other technologies that are substantially revising the way media industries do business and the way we receive messages" (p. 2). Center for Media Literacy (www.medialit.org) proclaimed that the culture we live in is not only a media culture, but also a multi-media culture, taking into account the numerous digital devices (gadgets) nowadays used to extract and produce communications, information and entertainment. Multimedia is a significant force in present day culture.

The same technology that has created not only different types of media texts, but also various methods of disseminating them. This, in turn, has facilitated the spread of those messages into different parts of the world in real time. Along 
with the media messages came the pervasion of the cultures they brought with them. We have seen how the youth of today uses the digital devices as well how they influence and shape the technology, content and usage of the network and providers. The ever more advanced and sophisticated musthave digital gadgets culture is worldwide. Media Smarts, Canada's Center for Digital and Media Literacy (mediasmarts.ca/digital-media-literacyfundamentals) observes that “today's youth are often called 'digital natives' by adults because of the seemingly effortless way they engage with all things digital ... . [They] live in an interactive, "on demand" culture where they are used to assessing media whenever and wherever they want." Instant-messaging, photo sharing, texting, social networking, video-streaming, and mobile Internet use are examples where youth have led the charge in new ways of engaging online, even changing societies and traditional cultures.

Indonesia is a country where the youth is fast emerging to become digital natives. The on top gadget used for networking in this country is the smart phone. To illustrate how this device has become a must-have-and-use in almost all layers in society is the reaction of one young domestic worker (who just moved from a small town in inland Central Java to Jakarta) to her employer's question why she broke up with her boyfriend: “He can't even 'open' a cellular phone (Buka handphone aja gak bisa)!" Surveys in 2013 show Indonesia of being the number 3 and number 4 user in the world of the online social network services Twitter and Facebook respectively. Twitter was founded and is managed by Americans and has its headquarters in San Francisco, California. Facebook, like Twitter, was also founded in America, is managed by Americans with its headquarters in Menlo Park, California. Twitter's mission, as they advertise it, states: "to give everyone the power to create and share ideas and information instantly, without barriers." Facebook's mission is "to give people the power to share and make the world more open and connected." Though the networks that are used in Indonesia are the translated (Indonesian) versions, the use of Twitter or Facebook inevitably brings with it the use of its culture. The users, then, of these two social networks have become 'natives' of the culture. The fact that Indonesia belongs to the top users of these networks shows that they have used the specific Twitter or/and Facebook culture and have become comfortable with it. This culture has seemingly merged with the local, e.g., language, style, etc., and has emerged as a newly created culture of their own.

If the two instances above show media culture that is adapted through the digital media, the older form of media, the TV, has had its own contribution of cultural mixing as well. An example of this is The American Idol, which is a reality show in the form of a singing competition. The format so far has shown a panel of three to four judges who offer their opinions on the contestants' performances in several layered sessions, elimination rounds in several big cities in 
America, and the final rounds for the select few who made it, in Hollywood, California. The show emphasizes viewers' participation in that the audience does selection of winners. Opinions from judges are to show judgment from experts' points of view. Judgment on the Idol as it is popularly called, is often times infamously harsh or even crude sometimes, which is one of the characteristics of the show. The show, created in America and distributed by an American media distributor, airs in Indonesia and since 2004 has had its Indonesian version, the Indonesian Idol, aired by an Indonesian TV outlet. This Indonesian show, which features Indonesian participants and a cast of judges who communicate in Indonesian, follows the format and method precisely as it is shown by the original, American production, including the sent offs when eliminated; harshness in giving judgments, etc. As a franchise, the culture the show brings with it is then taken as a given, and hence, followed, or even mimicked. As awkward as the process may have been in the adaptation of different values, especially criticizing a person before a big audience, the Indonesian version is now in its fourth episode. On top of that, the show's format, method, style and content has been adopted by other reality-singing contests with no American whatsoever franchising. Singing genres that are popularly known as 'belonging to Indonesia' such as dangdut has its own reality-singing contest show on Indonesian TV with a format that essentially copied the Idol style but with a variety of Indonesian undertones in it. Apart from the above, Indonesian TV stations have produced local versions of shows like the Voice (originally Dutch but aired and popularized by American TV, Master Chef (originally Australian) with Indonesian participants and Indonesian cast but almost everything else, format, method, style, content, are taken from the original.

The shows on TV above, as with the social networks on digital media, are just some examples of how media culture have been adopted and adapted and further on newly developed according to what is considered acceptable for the local public, in this sense, the Indonesian media audience. Norms, behaviors, styles, and so on, that are seemingly 'imported' but 'a must' in particular contexts, are just followed, merged into the local, and adhered to. The networks as well as the shows have their own followers and champions, those who have become 'natives' of the cultural space the media created.

Television news broadcast in America in the 90's, with the emergence of cable news, experienced a substantial change in news viewing. With constant 24/7 news barrage, the audience could access national as well as international news, including breaking news. In general, according to Breyer (2004), cable news networks are not only viewed at home but also at restaurants, bars, newsrooms, airport ratings rooms, hotel lobbies, and even in dispensary waiting rooms. This was because cable news networks succeeded in finding the perfect mix between news and entertainment, which the American TV viewers liked. In America, cable networks (spearheaded by $\mathrm{CNN}$ ) sent news 24 
hours a day and at the outset changed how Americans viewed television and how they seeked news. If in the past one had to wait until six o'clock in the evening to watch the news boadcast, with the advancement of cable, news was available at any time. Breyer quoted Walter Isaacson, CEO of CNN (Cable News Network) who says that news which attracted young viewers was the availability of four to five types of information. The young, according to Isaacson want to see at the same time weather, sports, headline news, and celebrities at the same time. The trademark of cable news networks became a mixture of hard news, soft news and entertainment, and became newstainment. Cable TV news united the American viewers to become a community who followed and gave attention to what they saw and heard, and who mostly fully believed what was announced and described by the cable news anchor.

Thanks to the same technology that brought the advancement of, American cable news media, a proliferation of domestic (Indonesian) cable TV providers, has entered the households of the Indonesian cable TV community. But with the news, the audience is also exposed to the culture behind the news. American news stories, in particular, mostly represent peculiar values and ideologies that portray the American dialectic "tug of war" between two different political leanings: the liberal and the conservative. Media bias in American news reportage has become a major issue. Bias in the news observed at the turn from the sixties to the seventies. Perception of news reportage until the end of the sixties had been that of unbiased stories, in strong adherence to contemporary journalistic codes and ethics. This view changed radically at the end of the sixties (1969) when the then Vice-President Of America, Spiro T. Agnew openly accused the news media in their reporting of President Richard Nixon's speech as being biased against the president (Ranney 1983). This incident became the first major occasion when bias in the news media became a controversial issue, widely debated by the press, universities, as well as the American public (Cirino, 1971). Media bias discourse that emerged in those days, according to Ranney, eventually became a partisan issue that has prevailed until the present. In the Indonesian context the news from the print media, network television channels and cable television channels inevitable will in general represent the bias or the views and ideologies from the owners.

Observing cable news representations in Indonesia, in many cases it looked like replicas of American cable news providers, looking at the format, method, and content. When cable programs newly emerged on Indonesian TV screens, an image of one TV cable station in Indonesia imitated exactly the iconic 'FOX NEWS' box at the bottom left side corner of the screen (with the cable station's own name displayed on it). The image has now disappeared. Another observable phenomenon is that Indonesian cable news providers have replicated or 
mimicked their American counterparts, be it program appearance (slogans, sight and sounds, electronic design displays) and performance (breaking news, ticker tapes, commercial inserts, talk show programs), among others.

When viewing graphic display and its audiences, particularly in the general election run-up, a tendency to news bias towards political leanings is noticeable. This is not surprising as it is wellknown that major Indonesian politicians are also owners of cable news providers, although the biases shown are not as sharply divided as in America. Basically the content and its methods are the same; the major difference lies in the Indonesian people as they appear significantly different, showing a vernacular (Indonesian) culture. What can be observed is that the American TV culture, especially that of cable news is readily adopted by the Indonesian TV practitioners with remarkable ease, adapted (mixed) with their own mores and norms, the intrinsic Indonesian culture, creating their own unique cable television ways of performing.

An interesting and very significant feature of cable news is the emergence of opinionated news. Opinion has become a major feature in cable network news. Westin (2005) argued that profit oriented business reasons have triggered an expansion and explosion opinionated journalism. In his opinion, expressing opinions is, among other reasons, easier, more efficient and a more effective way in attracting viewers, whereas reporting factual occurances needs hard work, is expensive, and inefficient. Cable news in Indonesia is very opinionated in nature, perhaps towards the extreme. Whether or not the same business reasons were behind the choice, obviously opinionated news programs are prominent successful features in these cable news programs. Perhaps ignorant of the characteristics of opinionated news, this practice has been willingly embraced, and has been developed in a very successful Indonesian way.

Upward mobility that has arisen from the contact and mixing of two media cultures, American and Indonesian, as the various instances above have shown, can be seen twofold: the media itself and its users (including practitioners). Indonesian cable news media performance have in the years since its birth improved significantly and has reached a high level of professionalism, the quality of news as well as the methods applied in conveying the message. The adaptation of the highly competitive American media culture in the more relaxed Indonesian media culture in the media domain proved to be very successful. Cable television providers with an enormous variety of programs and subscriber packages are now the norm, available to a huge slice of the Indonesian society. Indonesian television corporations have been expanding with dazzling rate and reaping huge amount advertisement revenues. The Indonesian television has reached levels that in the sixties were unthinkable. To come back to Tunstall's saying that the media are American, what can be observed is, the Indonesian television representing 
the Indonesian media is still 'American' but with a distinctive Indonesian cultural influence. Clearly the Indonesian media experienced an upward mobility movement, in quality, television stations, network and cable providers, and a diversity of audience. The upward mobility movement of the Indonesian audience has become far more huge, is better informed, is better educated, is more affluent, has a wider choice of outlets and programs, and has involved itself in issues that previously could only be participated and enjoyed by an elite group. The media audience is now powerful and are active players in the media community; the media audience rose also to another level; they experienced an upward mobility movement.

\section{AMERICAN CORPORATE CULTURE}

In the domain of corporate culture, hybridization in the context of commercial globalization or management is not a new process, the introduction of franchises like Kentucky Fried Chicken followed by MacDonald's and Starbuck, introduced preparation, serving and quality control of food products that eliminated the traditional practices and elevated the skills of the employees of those franchises to an accepted international level of food handling. The introduction to new (at that time contemporary) hygienic and quality food handling processes created an "upward mobility" of food handling and food processed product-retailing knowledge. The enormous boom of the 'resto' industry and franchising industry in Indonesia is certainly related to the early food- franchising era. E-commerce is the fastest growing retail business mode. Almost every product can be bought and sold through the Internet and at almost all locations in the world. The mix of credit cards and e-commerce make it possible to have global retail transaction delivered to almost any location. The cyberspace created a new way of politics and political interchange which started in America but is presently a major mode of political campaigning.

On more recent ICT products the same process is followed. Apple products like the I-phone, I-pad and Mac air computers are designed in America but are produced with components manufactured in all parts of the world. Marketing, promotion and sales are orchestrated and scripted in the Apple headquarters and meticulously executed in Apple shops all over the world. All the Apple shops follow the same design, management, and even the same policies, and are readily recognizable in the malls where they are located. The Apple Corporation's philosophy, corporate values, and management are "enforced" throughout the world. In the same fashion Apple's biggest and fiercest competitor Samsung is using exactly the same approach. What is happening is a hybridization process of American and Korean management practices styles all over the world in countries where the Apple and Samsung products are sold.

Pieterse (2010) argues that "hybridization as a process is as old as history but the pace of mixing accelerates and its scope widens in the wake of major structural changes, such as new technologies 
that enable new forms of intercultural contact and transnational contacts. Contemporary, accelerated globalization is such a new phase" (p. 1). Based on Pieterse's argument, we observe that the adaptation of American corporate culture and management style as a global management style to move upward in business organizations has been a hybridization process since the end of the Second World War.

The American way of management and production started in Western Europe with the Marshall Plan, a plan to rebuild Western Europe with American aid. In this 1945 post war period, argues Kipping (1996), American influence in political, military and economic power in the world reached a new height only countered by the communist ideology of the Soviet Union. The US Technical Assistance Program as part of the Marshall Plan offered an "apparently American successful management model" (p. 113), and the apparent superiority of American industrial organization.

The post-war management phenomena of apparent American management methodology superiority influenced also the Asian countries including Indonesia. At the end of the sixties the Indonesian economy was controlled by three organizations, the World Bank, The International Monetary Fund and The Inter-Governmental Group on Indonesia. With those organizations as sponsors, Indonesia was flooded with foreign companies like Siemens, British American Tobacco, Philips, Shell, Bechtel, Freeport, ALCOA, INCO, GM, Goodyear, USS, International Paper, ICI, ITT, and institutions such as USAID (Indonesia Digest, 2013). At the same time students from the Faculty of Economy of the University of Indonesia were sent to the University of California, Berkeley. Returning from America they became key members of the Indonesian Economy team, known as the 'Berkeley Mafia'. Together with the corporate culture and management style of foreign corporations operating in Indonesia and also oriented towards America, American corporate culture, management style and practices became hegemonic and dominant. Career development in corporations, or upward mobility was linked to mastering the American way. In line with the above development, subsequently, education on Economics, Management and Business in Indonesia became mainly oriented to the American Model. A Master of Business Administration degree became de facto a ticket to a better paying job and higher entrée level management position. In the nineties, to fulfill this demand of the MBA degrees, a flux of MBA programs were being offered in the big Indonesian cities to such extent that the Minister of Education regulated all those programs, and decreed that degree offered were called Magister Manajemen (MM) (Undip, 2014). The MM education programs were designed based on an academic approach. Currently, throughout Indonesia there are hundreds of MM programs offered by higher education institutions and are very popular. Even though MM programs have been run for more than two decades in Indonesia, not many of them have a professional orientation. Nevertheless, modern American management 
theory and practice were introduced through the American management literature that was the mainstay of management books used in MM programs. Popular books were readily translated in the Indonesian language and American management gurus were quoted in almost any management book in the Indonesian Language. US management concepts, ideas and phrases were the buzzwords in the Indonesia business schools and are still current. Peter Drucker and Jack Welch were elevated to an almost management deity status.

The same proliferation of business schools was also experienced in India. To cope with the increasing global commerce, India trains around 75,000 MBA's degrees annually (Gupta et al, 2003). Gupta et al observed that the "Indian business schools have sought to replicate the USbased organizational, pedagogical, curricula, industry interface and academic research model, but are struggling to introduce several adaptations because of differences in the work culture system" (n.p.). To cope with the increase of international commerce and the demand of business professionals, both countries, Indonesia and India, attempted to provide business education based on an American business school model but had to accept that adaptations were required to include cultural differences. Hybridization in the business school education became the norm. Western or American models were modified in all aspects of the business education. In Indonesia special decrees were even issued to regulate the business education.

A unique phenomenon is the Korean Model. If Gupta et al. argue that the American business school model which is based on a "hypercompetitive culture" is not attainable in India, in Korea this 'rat race' is accepted and is becoming the norm. Yang and Kum (2013) introduce three concepts that influence the socio-cultural characteristics of Korea. They define the concept of time hybridity where they argue that Koreans possess a combination of elements from traditional, modern and postmodern values simultaneously. In the same way, Koreans also experience space hybridity, a "mixture of values and characteristics from different regions" (p. 85). Due to the Japanese occupation and the Korean War, Koreans "aggressively replicate American and Japanese cultural values. In this way Koreans acquired both East Asian and European/North American values" (p. 87). Besides the concept of time/space hybridity, Yang \& Kum introduce the term cosmopolitan striving, "a metaphor for a collective motivation toward upward mobility in a transitional society from Asian or developing economies to modern and Western economies." Koreans, argue Yang \& Kum, have an obsession to achieve this. Learning the North American culture, especially education, "is also considered to be an important stepping stone to advance one's economic fate in society." To reach and achieve their cosmopolitan dream, Koreans are willing to work extraordinary hard far beyond other races. 
The discussions above bring forward the arguments that to achieve or to enjoy an upward mobility in Indonesia or developing economies, even such as India and Korea, embracing Western and especially North American cultures were the way to go. The usage of American media culture and technology is described above.

What is the present outlook on American management model compared to the Indonesian management model? MBA degrees or MM degrees in Indonesia are still sought after. As Hunter (2013) reports, "business, entrepreneurship and management courses are the fastest growing areas of education in South-East Asia" (n.p.). Particularly in the ASEAN region, for the reason upward career mobility, one requires a diploma, a degree, and some form of postgraduate qualifications." In general, according to Hunter (2013) those programs are highly influenced by imported management knowledge and preference for foreign expertise. Recognizing the gap between ASEAN leadership needed and the business education offered, there is an attitude change to the mixing of leadership style needed to succeed in the South-East Asian business world. Southeast Asian leadership characteristics are now considered essential for CEOs operating in corporations in the Asian market. Answering to the question "Asian and American Leadership Styles: How are they Unique?" Mills (2014) concludes that American and Asian leadership styles are different; "culture colors the way things are done." But it is also Mills' opinion that "as Asian companies seek access to world capital markets, they will move toward professional managers who will employ leadership styles more akin to those now used in the United States" (n.p.).

Management culture, style and practices, which are now prevalent in Indonesia, are without question based on the American management model. Management or business education in Indonesia was designed based on the MBA programs in the US and their graduates studied the American management knowledge and practices in the respective courses in the MBA program. Besides the business education institutions, American corporations operating in Asia also provided the practical and professional environment plus experiences in American management operations. The managers that were developed in the Indonesian business and commerce had their Indonesian cultures embedded in their American management culture and style. A management hybridization, which was and still is considered in Indonesia, is the path to a career upward mobility. In all aspects of Indonesian business and commerce, American management influence is the major influence and in most instances is proudly displayed by local corporations. Whether the Indonesian business community likes it or not, American management culture, style and practices are considered the road to success. Hybridization in Indonesian management is American management with Indonesian cultural undertones depending on from which region the managers come. 
With the incredible dependence of businesses on information and communication technology, which is dominated by American technology, it is hard to foresee in the future another form of management hybridization.

\section{CONCLUSION}

American media culture and American corporate culture in Indonesia are very dominant in their respective fields. The prevalent notion in the Indonesian media and business communities that are keeping up with the American development in media, and in the management knowledge and technology, ensures sustainable competitiveness in both fields. In news and entertainment media it is keeping track of the diversity of programs, scheduling and style of delivering, and in management the latest approaches and practices to increase profitability. However, tensions will still arise from this process of "keeping up" with the latest and newest inventions or approaches, such as the Indonesian cultural boundaries that inhibit or sometimes prohibit the implementation of those newest inventions.

Compared to the more individualistic and selfreliance values of Americans and their highly competitive culture, Indonesians are still very depended on community values and traditionally strife to a more harmonious approach. The balancing act between the American and Indonesian cultures and values in keeping up with newness is a hybridization process. A successful hybridization process results in progress and advancement, personally and institutionally. Upward mobility becomes then an individual and an institutional process. Hybridization in media and management in Indonesia is a delicate process, the diversity of the Indonesian nation and the written and perceived norms and regulations plus biases are very influential in the hybridization process. Resistance to change and reluctance to accept newness and embrace diversity are still stumbling blocks in accepting new cultures that are perceived alien to the existing cultures. On the other hand, Indonesia is on the leading edge in embracing new technology in information and communication technology or communication gadgets and social networks services. Balancing the above contradictions is also a cultural hybridization process, which perhaps will lead to a faster Indonesian progress in the media and management field.

\section{REFERENCES}

Adams, Brad. (2013). Closing the leadership gap in Asia. Singapore Management University. Retrieved from https://www.smu.edu.sg/perspectives/2013 /09/25/closing-leadership-gap-asia

Breyer, Richard. (2004). Newstainment, The world and I. 18. Washington.

Cirino, Robert. (1971). Don't blame the people: How the news media use bias, distorsion, and censorship to manipulate public opinion. Los Angeles: Diversity Press.

Gupta, Vipin, Kamala Gollakota and Ancheri Sreekumar. (2003). Quality in business education: A study of the Indian context. Paper prepared for and presented at the Business Education and Emerging Market Economies: Trends and Prospects Conference. Retrieved from 
www.ciber.gatech.edu/papers/workingpape r/2003/04-014.pdf

Ha, Kien Nghi. (2006). Crossing the border? Hybridity as late-capitalistic logic of cultural translation and national modernization. Retrieved from http://eipcp.net/transversal/1206/ha/en/pri nt

Hunter, Murray. (2013). No room for "Asian" business paradigms in Asian "B" schools? Retrieved from http://nsnbc.me/2013/12/18/room-asianbusiness-paradigms-asian-b-schools/

Jang, Wonho and Kim, Youngsun. (2013). Envisaging the sociocultural dynamics of K-pop: Time/space/hybridity, red queen's race, and cosmopolitan striving. Korea Journal, 53 (85-87). Retrieved from http://www.iwahs.org

Kipping, Matthias. (1996). The influence on the evolution of management consultancies in Britain, France, and Germany since 1945. Business and Economic History, 25 (113114). Retrieved from http://www.thebhc.org/publications/BE/pri nt/N02517/p0112.p0123.pdf

Kellner, Douglas M. (1995). Media Culture: Cultural studies, identity and politics between the modern and the postmodern. New York: Routledge.

Kellner, Douglas M. and Meenakshi Gigi Durham. (2006). Media and cultural studies. Malden, MA: Blackwell Publishing.

Kraidy, Marwan M. (2005). Hybridity: the cultural logic of globalization. Philadelphia, PA: Temple University Press.
Mills, D. Quinn. (2005). Asian and American leadership styles: How are they unique? Retrieved http://hbswk.hbs.edu/item/4689.html

Pieterse, Jan Nederveen. (2010). Globalization goes in circles: Hybridities East-West. Retrieved from http://www.socialtheory.en/texts/pieterseglobalization-goes-in-circles.pdf

Potter, W, James. (2008). Media Literacy. Los Angeles: Sage Publication.

Raab, Josef and Martin Butler. (2008). Introduction: Cultural hybridity in the Americas. Retrieved from http://www.unibielefeld.de/(de)/ZIF/FG/.../raabButler_intro-hybrid.pdf

Ranney, Austin. (1983). Channels of power: The impact of television on American politics. New York: Persues Books.

Sejarah dan perkembangan UNDIP. (2011). Program MM UNDIP. Retrieved from http://www.mm.undip.ac.id/index.php? option $=$ com content\&view $=$ article $\& i d=4$ \&itemid $=9$

The Suharto years. (2014). Indonesia Digest. Retrieved from http://www.indonesiadigest.net/3302.suharto.htm.

Tomlinson, John. (1999). Globalization and culture. Chicago: The University of Chicago Press

Tunstall, Jeremy. (1977). The media are American: Anglo American media in the world. New York: Columbia University Press. 
